\title{
THE EFFECTS OF LIPOTROPIC FACTORS ON PHOSPHOLIPIDE TURNOVER IN THE PLASMA OF NORMAL PERSONS AS INDICATED BY RADIOACTIVE PHOSPHORUS ${ }^{1}$
}

\author{
By W. E. CORNATZER AND DAVID CAYER \\ (From the Departments of Biochemistry and Internal Medicine, Bowman Gray School of \\ Medicine of Wake Forest College and the North Carolina Baptist Hospital, \\ Winston-Salem, N. C.)
}

(Submitted for publication August 11, 1949; accepted, January 9, 1950)

The action of choline and methionine in preventing or curing the fatty infiltration of the liver which is produced experimentally in animals by low protein diets is believed to result from an increased turnover of phospholipides in the liver $(1,2)$. Since this organ is the main, if not the sole, source of phospholipides in plasma (3), it would seem that changes in the formation of phospholipides in the liver would be reflected by corresponding changes in the amounts of newly formed phospholipides in the plasma (4). No methods were available for the determination of newly formed plasma phospholipides until isotopic techniques were developed and radioactive tracers became available.

It is now possible to study the formation of plasma phospholipides following the administration of radioactive phosphorus, and to obtain an indication of the turnover of these compounds in the liver. Few data of this sort are available for human subjects, however. Hence, it became necessary to estimate the turnover in normal persons, before the effects of lipotropic agents such as choline and methionine could be investigated and information could be obtained on the mode of action and possible therapeutic application of these substances.

Preliminary experiments to determine the validity of the method for determining the radioactivity and phosphorus of the plasma lipides in persons with and without liver disease were done and the results obtained were used to calculate the turnover of phospholipides (specific activity) (5).

\footnotetext{
1 This investigation was supported (in part) by a research grant from the Division of Research Grants and Fellowships of the National Institutes of Health, U. S. Public Health Service. The $P^{22}$ used in these experiments was obtained from the National Laboratories, Oak Ridge, Tenn., on allocation from the United States Atomic Energy Commission.
}

The study was then extended to include simultaneous determinations on the inorganic and lipide fractions of the plasma, so that the isotopic concentration in the lipides could be expressed as a function of the concentration of the inorganic phosphate- "relative specific activity" (6).

Under the conditions of our experiments, an increase in the formation of phospholipides may reasonably be assumed when higher values for the total radioactivity are found, and when the specific activity values are also higher or are the same. However, such a conclusion is valid only if the time curve of the specific activity of the inorganic fraction remains the same. Various factors, such as differences in the rate of absorption and in the equilibrium between intra- and extracellular specific activity of the inorganic phosphorus, may conceivably produce changes in the specific activity of the inorganic fraction. Comparison of the relative specific activity should provide a means of reducing these causes of error.

Preliminary study showed that the liver turnover of phospholipides as measured in the plasma varied widely in different individuals. In this study, therefore, comparisons were based on data obtained in the same individual with and without the administration of lipotropic compounds in order to interpret the results obtained in pathologic states before, during, and after treatment with these substances.

\section{MATERIAL}

\section{Group 1: Controls not receiving choline or methionine}

This group consisted of 13 persons-10 men and three women-having no clinical evidence of organic disease. The ages varied from 19 to 47 years. Preliminary data on the lipide phosphorus of seven of these individuals were used as controls for a previous study (5). 


\section{Group 2: Controls receiving choline or methionine}

Six other persons, three men and three women, were studied in a similar fashion before and after the administration of a single large dose of choline chloride (or its equivalent as choline dihydrogen citrate) or methionine (d1) $(10 \mathrm{Gm}$.). These persons fell in the same age group as those in Group 1, and likewise had no clinical evidence of organic disease. Data on the lipide phosphorus of three of these individuals have been reported (5). Three of the group were studied again after a twomonth interval during which they received no lipotropic factors.

During the interval of study, all the controls ate their usual diet, which was assumed to be adequate in dietary essentials. They took no medication. None of them had any marked change in activity, general health, or well being.

\section{METHODS}

All individuals were given an intramuscular injection of radiophosphorus ( 0.5 millicuries) in the form of $\mathrm{NaH}_{2} \mathrm{PO}_{4}$. Blood samples were taken routinely at the time of injection, ${ }^{2} 24$ hours, and often at six, 48, 72, and 96 hour intervals. The plasma was separated from the oxalated blood by centrifugation and divided into two fractions of 5 and $8 \mathrm{cc}$. each. From one fraction the lipides were extracted with hot ethyl alcohol and alcoholether, and purified with chloroform (7). The radioactivity (8) and the phosphorus content (9) were determined on aliquots of the chloroform solution. The second fraction of the plasma was extracted with trichloracetic acid, and the inorganic phosphorus was determined on an aliquot of this extract (9). Another aliquot of the trichloracetic acid extract was treated with strychnine molydate (10), and the precipitate dissolved in acetone. After evaporation of the solvent, the radioactivity of the inorganic phosphate was determined (8).

Urine was collected from several individuals during a three-hour period 21 to 24 hours after the injection of

2 When the experiments were repeated in the same individual after a two month interval, the sample collected at the time of injection did not exhibit any radioactivity, either in the inorganic or in the lipide fraction.

TABLE I

Plasma phospholipide turnover in Group 1 individuals

(See TABLE I-Continued, next page)

\begin{tabular}{|c|c|c|c|c|c|c|c|c|c|c|c|c|}
\hline \multirow{3}{*}{ Name, age, sex } & \multirow{3}{*}{$\begin{array}{c}0 \text { hour } \\
\begin{array}{l}\text { Phosphorus } \\
\text { mg./100 cc. }\end{array} \\
\text { Lipide* }\end{array}$} & \multicolumn{7}{|c|}{24 hours } & \multicolumn{4}{|c|}{48 hours } \\
\hline & & \multicolumn{2}{|c|}{$\begin{array}{l}\text { Phosphorus } \\
m g . / 100 \text { cc. }\end{array}$} & \multicolumn{2}{|c|}{$\begin{array}{l}\text { Radioactivity } \dagger \\
\text { r.r.u./100 cc. }\end{array}$} & \multicolumn{2}{|c|}{$\begin{array}{c}\text { Specific activity } \\
\times 100\end{array}$} & \multirow{2}{*}{$\begin{array}{c}\text { Relative } \\
\text { specific, } \\
\text { activity } \\
\times 100\end{array}$} & \multicolumn{2}{|c|}{$\begin{array}{l}\text { Phosphorus } \\
m g . / 100 \mathrm{cc} .\end{array}$} & \multicolumn{2}{|c|}{$\begin{array}{l}\text { Radioactivityt } \\
\text { r.r.u./100 cc. }\end{array}$} \\
\hline & & Inorg. & Lipide & Inorg. & Lipide & Inorg. & Lipide & & Inorg. & Lipide & Inorg. & Lipide \\
\hline E. C. $39 \mathrm{M}$ & 7.88 & & 7.4 & & 1.116 & & 15.1 & & & 7.29 & & 1.560 \\
\hline H. P. Y. $35 \mathrm{M}$ & 8.25 & & 7.68 & & 0.476 & & 6.2 & & & 7.11 & & 0.838 \\
\hline J. H. W. $47 \mathrm{M}$ & & & 5.74 & & 0.990 & & 17.2 & & & & & \\
\hline F. R. L. $37 \mathrm{M}$ & 8.26 & & 7.18 & & 0.768 & & 10.7 & & & & & \\
\hline L. M. B. 19 F & 2.43 & & 2.18 & & 0.434 & & 19.9 & & & & & \\
\hline C. W.W. $37 \mathrm{M}$ & 7.68 & & 6.70 & & 0.646 & & 9.6 & & & & & \\
\hline M. S. $19 \mathrm{M}$ & 5.30 & & 5.90 & & 0.506 & & 8.6 & & & & & \\
\hline B. G. S. $28 \mathrm{~F}$ & 8.68 & & 7.70 & & 1.138 & & 14.8 & & & & & \\
\hline N. C. T. 27 F & 8.08 & & 7.80 & & 0.501 & & 6.4 & & & & & \\
\hline R. E. K. $24 \mathrm{M}$ & 5.28 & 3.45 & 5.68 & 1.880 & 1.365 & 54.5 & 24.0 & 44.0 & 4.04 & 5.60 & 0.750 & 0.921 \\
\hline $\begin{array}{lll}\text { A. I. } & 47 \quad \mathrm{M} \\
\end{array}$ & 6.60 & 1.99 & 7.93 & 0.578 & 1.080 & 29.0 & 13.6 & 46.8 & 2.28 & 7.19 & 0.458 & 1.400 \\
\hline J. O. D. $33 \mathrm{M}$ & 5.69 & 1.64 & 6.24 & 0.686 & 0.524 & 41.8 & 8.4 & 20.0 & 1.85 & 4.13 & 0.485 & 0.552 \\
\hline $\begin{array}{lll}\text { S. G. } & 34 \quad \mathrm{M} \\
\end{array}$ & 3.25 & 1.24 & 2.08 & 0.454 & 0.345 & 36.6 & 16.6 & 45.4 & 2.35 & 3.15 & 0.687 & 0.485 \\
\hline Mean & 6.44 & 2.08 & 6.17 & 0.898 & 0.760 & 40.4 & 13.1 & 39.0 & 2.63 & 5.74 & 0.595 & 0.839 \\
\hline G & 2.0 & 0.95 & 1.97 & 0.65 & 0.35 & 10.9 & 5.4 & 12.7 & 0.96 & 1.7 & 0.14 & 0.41 \\
\hline $\begin{array}{l}\text { Standard } \\
\text { deviation } \%\end{array}$ & 31 & 46 & 32 & 72 & 46 & 27 & 41 & 33.0 & 37 & 30 & 24 & 49 \\
\hline $\begin{array}{l}\text { Standard error } \\
\text { of mean }\end{array}$ & 0.60 & 0.48 & 0.54 & 0.33 & 0.09 & 5.45 & 1.50 & 6.35 & 0.48 & 0.72 & 0.07 & 0.21 \\
\hline
\end{tabular}

* At time of injection of radioactive phosphorus.

$\dagger$ Expressed in relative radioactivity units (r.r.u.), the total dose injected being equal to $10^{4}$ r.r.u. (This is 100 times the percentage of the dose of $P^{*}$ injected which is found in the phospholipides). 
TABLE I-Contirued

Plasma phospholipide turnover in Group 1 individuals

\begin{tabular}{|c|c|c|c|c|c|c|c|c|c|c|c|c|}
\hline \multirow{3}{*}{$\begin{array}{c}\text { Patient } \\
\text { Name, age, sex }\end{array}$} & \multicolumn{3}{|c|}{48 hours } & \multicolumn{7}{|c|}{96 hours } & \multirow{3}{*}{$\begin{array}{c}\begin{array}{c}\text { Specific } \\
\text { activity } \\
\text { of urine } \\
\text { inorganic } \\
\text { phosphorus } \\
\times 100\end{array} \\
21-24 \mathrm{hr} .\end{array}$} & \multirow{3}{*}{$\begin{array}{c}\begin{array}{c}\text { Ratio of } \\
\text { specific } \\
\text { activities } \\
\text { of urine P } \\
\text { plasma P }\end{array} \\
\frac{21-24 \mathrm{hr}}{24 \mathrm{hr} .}\end{array}$} \\
\hline & \multicolumn{2}{|c|}{$\begin{array}{c}\text { Specific activity } \neq \\
\times 100\end{array}$} & \multirow{2}{*}{$\begin{array}{c}\begin{array}{c}\text { Relative } \\
\text { opecific } \\
\text { activity } \$ \\
\times 100\end{array} \\
\text { Lipide }\end{array}$} & \multicolumn{2}{|c|}{$\begin{array}{l}\text { Phosphorus } \\
\text { ms./100 cc. }\end{array}$} & \multicolumn{2}{|c|}{$\begin{array}{c}\text { Radioactivity } \\
\text { r.r.u./100 cc. }\end{array}$} & \multicolumn{2}{|c|}{$\begin{array}{c}\text { Specific activity } \ddagger \\
\times 100\end{array}$} & \multirow{2}{*}{$\begin{array}{c}\begin{array}{c}\text { Relative } \\
\text { specific } \\
\text { activity } \$ \\
\times 100\end{array} \\
\text { Lipide }\end{array}$} & & \\
\hline & Inorg. & Lipide & & Inorg. & Lipide & Inorg. & Lipide & Inorg. & Lipide & & & \\
\hline $39 \mathrm{M}$ & & 21.4 & & & 8.70 & & 1.689 & & 19.4 & & & \\
\hline H. P. Y. 35 M & & 11.8 & & & 7.97 & & 0.996 & & 12.5 & & & \\
\hline J. H. W. 47 M & & & & & & & & & & & & \\
\hline F. R. L. 37 M & & & & & & & & & & & & \\
\hline L. M. B. $19 \mathrm{~F}$ & & & & & & & & & & & & \\
\hline C. W. W. 37 M & & & & & & & & & & & & \\
\hline M. S. $19 \mathrm{M}$ & & & & & & & & & & & & \\
\hline B. G. S. 28 F & & & & & & & & & & & & \\
\hline N. C. T. 27 F & & & & & & & & & & & & \\
\hline R. E. K. 24 M & 18.5 & 16.4 & 88.6 & & & & & & & & 28.8 & 0.53 \\
\hline $47 \mathrm{M}$ & 20.0 & 19.5 & 97.5 & 1.82 & 6.75 & 0.252 & 1.240 & 13.9 & 18.4 & 132.0 & 12.4 & 0.43 \\
\hline J. O. D. $33 \mathrm{M}$ & 26.2 & 13.4 & 51.1 & & & & & & & & 37.3 & 0.89 \\
\hline S. G. $34 \mathrm{M}$ & 29.2 & 15.4 & 52.8 & & & & & & & & 52.0 & 1.42 \\
\hline Mean & 23.5 & 16.3 & 72.5 & 1.82 & 7.80 & 0.252 & 1.308 & 13.9 & 16.8 & 132.0 & 32.6 & 0.82 \\
\hline $\mathbf{G}$ & 5.1 & 3.6 & 24.0 & & & & & & & & & \\
\hline $\begin{array}{l}\text { Standard } \\
\text { deviation } \%\end{array}$ & 21 & 22 & 33 & & & & & & & & & \\
\hline $\begin{array}{l}\text { Standard error } \\
\text { of mean }\end{array}$ & 2.55 & 1.48 & 12.0 & & & & & & & & & \\
\hline
\end{tabular}

$\ddagger$ Specific activity is the ratio of the radioactivity (in r.r.u.) to the phosphorus (in mg.) in the extracts.

$\$$ Relative specific activity of plasma phospholipides is the ratio of the specific activity of the phospholipides to that of the inorganic phosphate.

radiophosphorus. One cc. of the urine samples was evaporated to dryness, and the radioactivity read directly (8). In another aliquot the phosphorus content was determined without previous mineralization (9).

In the tables the radioactivity has been expressed in relative radioactivity units (r.r.u.), the total dose injected being assumed to be $10^{4}$ r.r.u. The specific activity is the ratio of radioactivity (in r.r.u.) to the phosphorus (in milligrams). Relative specific activity (6) is the ratio of the specific activity of the plasma phospholipides to that of the inorganic phosphate.

\section{RESULTS}

Turnover of plasma phospholipides in Group 1 (Table I and Figure 1)

\section{Lipide phosphorus}

The level of lipide phosphorus in the plasma of the various individuals at the time of injection of radiophosphorus varied between 2.43 and 8.68 $\mathrm{mg} . / 100 \mathrm{cc}$., with a mean value of $6.44 \mathrm{mg} . / 100$ cc. and a standard deviation of 31 per cent. The determinations in the same individual during the 96 hour interval showed a much smaller variability. In the 13 individuals who made up Group 1, the standard deviation from one individual mean averaged 9 per cent.

The radioactivity and specific activity values determined at a given interval also showed considerable variation between individuals ( 43 and 41 per cent respectively at the 24th hour, and 49 and 22 per cent at the 48th hour). In Figure 1, the specific activities are plotted against time. It is apparent that by the 48th hour the curves generally tend to level into a plateau, the mean values for the specific activity at 24,48 , and 96 hours being $13.1,16.3$, and 16.8 respectively. 


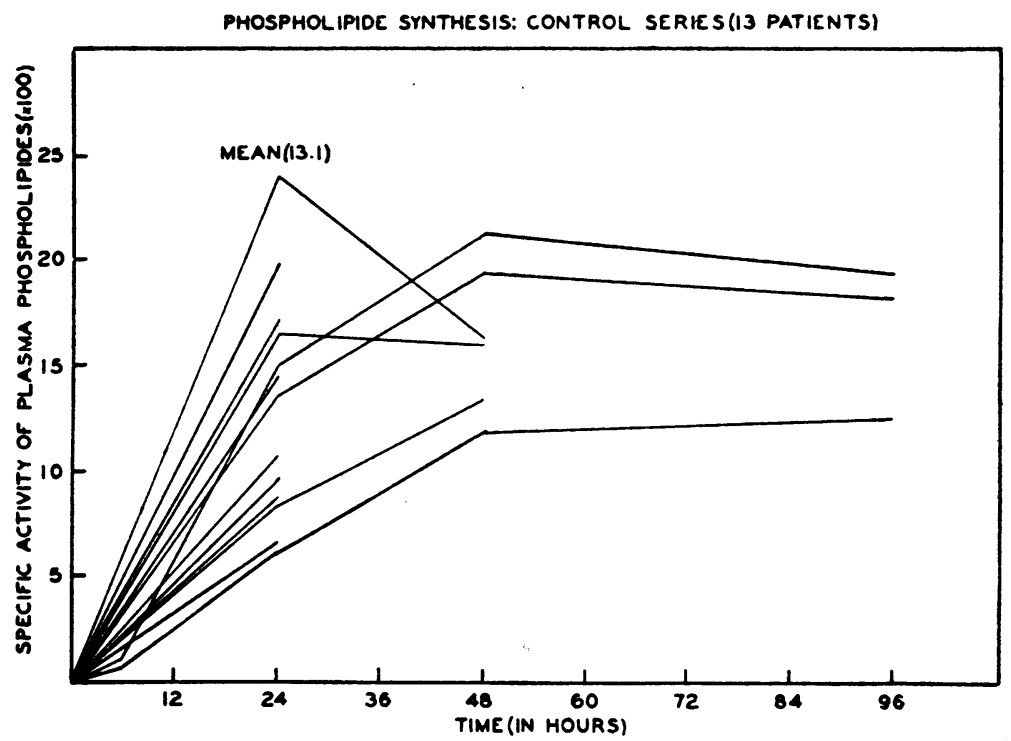

FIG. 1.

\section{Inorganic phosphorus}

The values for inorganic phosphorus varied between 1.2 and $4.0 \mathrm{mg} . / 100 \mathrm{cc}$. of plasma in different individuals (average at the 24th hour 2.1. mg./100 cc., with a standard deviation of 46 per cent). In four individuals in whom repeated determinations were made, the level remained rather constant over the 96 hour period of study. The radioactivity and specific activity of the plasma inorganic phosphorus also varied considerably in the different individuals (standard deviation at the 24th hour 72 and 27 per cent respectively). In each individual subject both radioactivity and specific activity of the inorganic phosphorus showed a progressive decrease during the 96 hour period.

\section{Relative specific activity of the lipide phosphorus}

The ratio of the specific activity of the lipide phosphorus to that of the inorganic phosphorus does not adequately express the incorporation of the inorganic phosphate into the phospholipide molecule. However, it seems probable that the comparison of these ratios would minimize the influence of individual variation in the specific activity of the inorganic phosphate (11).

\section{Urine phosphorus}

Urine phosphate determinations on a three hour collection (21st to 24 th hour) were made in only four individuals. In three of these the ratio between the specific activities of the inorganic phosphorus in the urine and in the plasma varied between 0.43 and 0.89 . In only one person (S. G.) was this ratio greater than 1 . The possible factors influencing this ratio will be discussed in a later paper on the basis of a greater number of determinations.

\section{Effect of a single dose of choline on the turnover of plasma phospholipides in Group 2 (Table II and Figure 2)}

The administration of choline (to five individuals) or of methionine (to one individual) did not cause a significant change in the level of lipide phosphorus. In all six individuals in Group 2, the radioactivity and specific activity of the lipide phosphorus 24 and 48 hours after administration of the lipotropic agent fell within the range of the corresponding values obtained in normal individuals to whom no choline or methionine was administered (Group 1).

In the three individuals who received another injection of $\mathrm{P}^{32}$ two months later, no difference was noted in the values for lipide or inorganic phosphorus, radioactivity; or specific activity before or after the administration of a single large dose of choline (Figure 2).

In all six individuals the radioactivity and specific activity values of the plasma phospholipides 


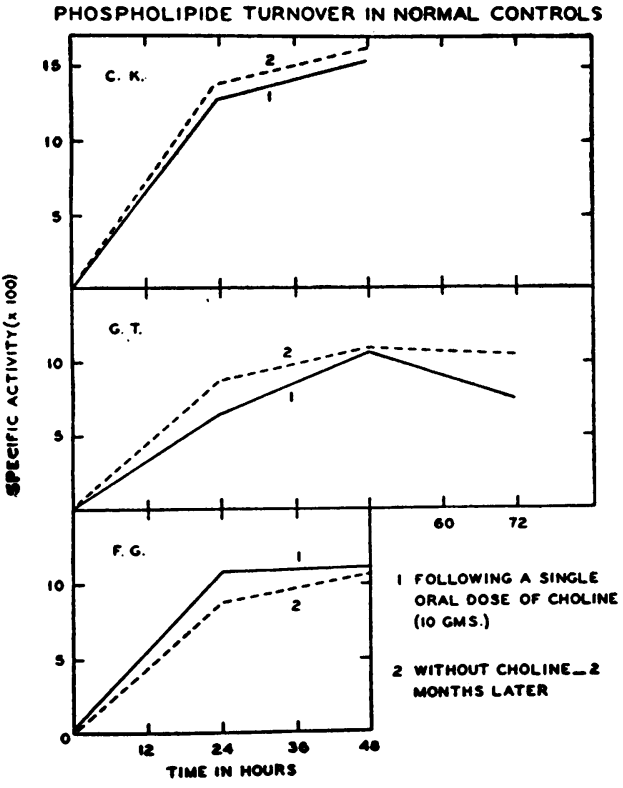

FIG. 2.

fell within the range of those obtained in the controls to whom no methionine or choline was administered (Table II). If the relative specific activities obtained at the same time interval in the same individual are compared, the values after giving choline are either approximately the same as those obtained two months later without the administration of the lipotropic substance, or are somewhat lower.

\section{DISCUSSION}

In an effort to determine the effect of choline and methionine in stimulating phospholipide synthesis by the liver $(1,2)$, we have injected isotopic phosphorus in normal persons, and have determined the phosphorus level and the radioactivity both in the inorganic and in the lipide fraction of the plasma before and after the administration of lipotropic substances. Thus the isotopic concentration in the lipide phosphorus could be expressed either as specific activity or as relative specific activity. It appears that the 24 and 48 hour intervals following the injection of radiophosphorus are the most suitable for comparison of the data. These intervals correspond to the ascending part of the specific activity-time curves, where the synthesis of phospholipides exceeds their breakdown or catabolism. Hence, the ra-

TABLE II

Phospholipide turnover in normal individuals before and after a single large dose of choline or methionine

(See TABLE II-Continued, next page)

\begin{tabular}{|c|c|c|c|c|c|c|c|c|c|c|c|c|c|c|}
\hline \multirow{3}{*}{$\begin{array}{c}\text { Patient } \\
\text { Name, age, sex }\end{array}$} & \multirow{3}{*}{$\begin{array}{l}\text { No. of } \\
\text { injec- } \\
\text { tions of } \\
\text { Pas }\end{array}$} & \multirow{3}{*}{$\begin{array}{c}\text { Material } \\
\text { given }\end{array}$} & \multirow{3}{*}{$\begin{array}{c}0 \text { hour } \\
\begin{array}{c}\text { Phos- } \\
\text { phorus } \\
m g . /\end{array} \\
100 \mathrm{cc} .\end{array}$} & \multicolumn{7}{|c|}{24 hours } & \multicolumn{4}{|c|}{48 hours } \\
\hline & & & & \multicolumn{2}{|c|}{$\begin{array}{l}\text { Phosphorus } \\
\text { mg./100 cc. }\end{array}$} & \multicolumn{2}{|c|}{$\begin{array}{l}\text { Radioactivityt } \\
\text { r.r.u./100 cc. }\end{array}$} & \multicolumn{2}{|c|}{$\begin{array}{c}\text { Specific } \\
\text { activity } \\
\times 100\end{array}$} & \multirow{2}{*}{$\begin{array}{c}\begin{array}{c}\text { Relative } \\
\text { specific } \\
\text { activity } \$ \\
\times 100\end{array} \\
\text { Lipide }\end{array}$} & \multicolumn{2}{|c|}{$\begin{array}{l}\text { Phosphorus } \\
\text { mg./100 cc. }\end{array}$} & \multicolumn{2}{|c|}{$\begin{array}{l}\text { Radioactivityt } \\
\text { r.r.u./100 cc. }\end{array}$} \\
\hline & & & & Inorg. & Lipide & Inorg. & Lipide & Inorg. & Lipide & & Inorg. & Lipide & Inorg. & Lipide \\
\hline B. J. H. 48 F & 1 & Choline & 3.23 & & 4.37 & & 0.597 & & 13.7 & & & & & \\
\hline O. H. H. 61 F & 1 & Methionine & $\mathbf{8 . 8 5}$ & & 8.40 & & 0.493 & & 5.9 & 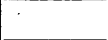 & & 8.73 & & 1.090 \\
\hline R. A. B. $25 \mathrm{M}$ & 1 & Choline & 4.88 & 3.04 & 5.38 & 0.832 & 0.577 & 27.4 & 10.7 & 39.0 & 3.16 & 6.40 & 0.575 & 0.996 \\
\hline \multirow[t]{2}{*}{ G. T. $27 \mathrm{M}$} & 1 & Choline & 6.00 & 3.94 & 6.44 & 0.835 & 0.428 & 21.2 & 6.7 & 31.4 & 3.32 & 6.38 & 0.500 & 0.688 \\
\hline & 2 & Water & 6.85 & 4.24 & 5.46 & 0.808 & 0.490 & 19.1 & 9.00 & 46.9 & 3.64 & 6.64 & 0.482 & 0.730 \\
\hline \multirow[t]{2}{*}{ F. G. $\quad 26 \mathrm{M}$} & 1 & Choline & 5.08 & 3.55 & 6.45 & 1.246 & 0.690 & 35.1 & 10.7 & 30.5 & 4.18 & 5.13 & 0.575 & 0.568 \\
\hline & 2 & Water & 7.85 & 3.90 & 7.86 & 0.855 & 0.690 & 21.9 & 8.8 & 40.0 & 3.38 & 7.68 & 0.485 & 0.840 \\
\hline \multirow[t]{2}{*}{ C. K. 25 F } & 1 & Choline & 6.63 & 2.80 & 6.64 & 0.800 & 0.860 & 28.6 & 12.9 & 45.1 & 2.50 & 6.02 & 0.476 & 0.924 \\
\hline & 2 & Water & 5.97 & 3.08 & 6.18 & 0.856 & 0.858 & 27.7 & 13.9 & 50.2 & 2.88 & 5.85 & 0.534 & 0.950 \\
\hline Mean|l & & & 5.78 & 3.33 & 6.28 & 0.928 & 0.608 & 28.1 & 10.1 & 36.5 & 3.29 & 6.53 & 0.530 & 0.853 \\
\hline G & & & 1.90 & 0.51 & 1.35 & 0.21 & 0.023 & 5.7 & 3.1 & 6.9 & 0.69 & 1.3 & 0.05 & 0.22 \\
\hline $\begin{array}{l}\text { Standard } \\
\text { deviation \% }\end{array}$ & & & 33 & 15 & 22 & 23 & 24 & 20 & 33 & 19 & 21 & 20 & 9 & 26 \\
\hline $\begin{array}{l}\text { Standard error } \\
\text { of mean }\end{array}$ & & & 0.77 & 0.25 & 0.55 & 0.10 & 0.01 & 0.28 & 1.29 & 3.45 & 0.34 & 0.59 & 0.02 & 0.09 \\
\hline
\end{tabular}

*t+8 See footnotes to Table I.

II With lipotropic agent. 
TABLE II-Continued

Phospholipide turnover in normal individuals before and after a single large dose of choline or methionine

\begin{tabular}{|c|c|c|c|c|c|c|c|c|c|c|c|c|}
\hline \multirow{3}{*}{ Name, age, sex } & \multirow{3}{*}{$\begin{array}{l}\text { No. of } \\
\text { injec- } \\
\text { tions of } \\
\text { Pas }\end{array}$} & \multirow{3}{*}{$\underset{\text { Material }}{\text { given }}$} & \multicolumn{3}{|c|}{48 hours } & \multicolumn{7}{|c|}{72 hours } \\
\hline & & & \multicolumn{2}{|c|}{$\begin{array}{c}\text { Specific activity } \ddagger \\
\times 100\end{array}$} & \multirow{2}{*}{$\begin{array}{c}\begin{array}{c}\text { Relative } \\
\text { specific } \\
\text { activity } \\
\times 100\end{array} \\
\text { Lipide }\end{array}$} & \multicolumn{2}{|c|}{$\begin{array}{l}\text { Phosphorus } \\
\text { mg./100 cc. }\end{array}$} & \multicolumn{2}{|c|}{$\begin{array}{l}\text { Radioactivity } \dagger \\
\text { r.r.u./100 cc. }\end{array}$} & \multicolumn{2}{|c|}{$\begin{array}{c}\text { Specific activity } \ddagger \\
\times 100\end{array}$} & \multirow{2}{*}{$\begin{array}{c}\begin{array}{c}\text { Relative } \\
\text { specific } \\
\text { activity } \\
\times 100\end{array} \\
\text { Lipide }\end{array}$} \\
\hline & & & Inorg. & Lipide & & Inorg. & Lipide & Inorg. & Lipide & Inorg. & Lipide & \\
\hline B. J. H. 48 F & 1 & Choline & & & & & & & & & & \\
\hline O. H. H. 61 F & 1 & Methionine & & 12.5 & & & & & & & & \\
\hline R. A. B. $25 \mathrm{M}$ & 1 & Choline & 18.2 & 15.6 & 85.8 & & & & & & & \\
\hline \multirow[t]{2}{*}{ G. T. $27 \mathrm{M}$} & 1 & Choline & 15.1 & 10.8 & 71.5 & 3.36 & 4.83 & 0.392 & 0.360 & 11.6 & 7.5 & 64.7 \\
\hline & 2 & Water & 13.3 & 11.0 & 82.8 & 3.47 & 7.35 & 0.402 & 0.773 & 11.6 & 10.5 & 90.5 \\
\hline \multirow[t]{2}{*}{ F. G. $26 \mathrm{M}$} & 1 & Choline & 13.8 & 11.1 & 80.5 & & & & & & & \\
\hline & 2 & Water & 14.4 & 10.9 & 75.7 & & & & & & & \\
\hline \multirow[t]{2}{*}{ C. K. $25 \mathrm{~F}$} & 1 & Choline & 19.0 & 15.3 & 80.5 & & & & & & & \\
\hline & 2 & Water & 18.5 & 16.2 & 87.6 & & & & & & & \\
\hline Mean || & & - & 16.5 & 13.0 & 79.5 & 3.41 & 6.09 & 0.397 & 0.566 & 11.6 & 9.0 & 77.6 \\
\hline G & & & 2.4 & 2.2 & 5.9 & & & & & & & \\
\hline $\begin{array}{l}\text { Standard } \\
\text { deviation \% }\end{array}$ & & & 15 & 17 & 7 & & & & & & & \\
\hline $\begin{array}{l}\text { Standard error } \\
\text { of mean }\end{array}$ & & & 1.24 & 1.01 & 2.97 & & & & & & & \\
\hline
\end{tabular}

dioactivity values correspond chiefly to the phospholipides synthesized from the inorganic phosphate during these intervals.

\section{Variations in normal individuals without lipo- tropic substances}

Our previous statement concerning the variability of the level of lipide phosphorus in different individuals and its relative constancy in the same person was confirmed and extended (5). This level was found to be comparable in the same individual even when the determinations were repeated after an interval of several months. Likewise, on the basis of the present and previous determinations, it is apparent that there is a wide variability between individuals in the turnover of phospholipides in plasma. Individual variations are still considerable, although less extensive, if the values are expressed as relative specific activity instead of specific activity.

\section{Effect of a single large dose of lipotropic material on phospholipide synthesis}

No significant difference in the plasma phospholipide phosphorus was found between the group of persons who were given a single large dose of a lipotropic substance and those who were not. However, in view of the wide individual variability in both the level of phospholipide phosphorus and the phospholipide formation, we felt that the same individual should be used as his own control in order to detect any significant change which might occur as a result of the administration of lipotropic substances. Accordingly, the phospholipide turnover following a single large dose of choline was studied in three normal individuals and two months later the experiments were repeated in the same individuals without the administration of this substance. No significant difference in the phospholipide levels of these individuals was noted in the two experiments, and the specific activity-time curves were essentially unchanged. The values of both specific activity and relative specific activity following the administration of choline were no higher than those found in the experiment in which the individual did not receive these substances.

In experimental animals receiving a high-fat, low-choline diet, the ingestion of a single massive dose of choline has a marked stimulatory effect on the conversion of inorganic phosphate into plasma phospholipides, this effect reflecting the 
increase in phospholipide synthesis in the liver (12). In animals on adequate diets containing an abundant supply of choline or choline precursors, the effect is smaller or not apparent (1). It seems that, in animals, the stimulatory action of a large dose of lipotropic substances is detectable only if the phospholipide synthesis is limited by the dietary supply of choline or choline precursors.

We have previously reported a few data on the effect of a large dose of choline or methionine on phospholipide turnover in normal persons and in patients with chronic hepatitis $(5,13)$. To our knowledge, no other data are available in the literature concerning the action of a single massive dose of choline or methionine on phospholipide formation in normal human subjects. In our present experiments on normal individuals the administration of a single large dose of a lipotropic substance apparently did not accelerate the turnover of phospholipides in the plasma (nor, presumably, in the liver).

If the effects of choline in human beings are analogous to those in animals, our present results obtained in persons without clinical or laboratory evidence of liver disease would indicate that the dietary supply of lipotropic substances or of their precursors was adequate.

\section{SUMMARY}

Following the administration of radioactive phosphorus to a group of normal individuals, the radioactivity and phosphorus level in the inorganic and lipide fractions of the plasma were determined. The values of the specific activity or relative specific activity have been taken as an indication of the turnover of phospholipides in the plasma, possibly reflecting the synthesis of phospholipides in the liver.

On the basis of the present study and previous experiments, it appears that the phospholipide turnover as measured in the plasma of normal persons varies widely between individuals but is fairly constant in the same individual.

In several subjects the phospholipides were studied after the ingestion of a large dose of choline or methionine. This was repeated two months later in the same individuals without the adminis- tration of the lipotropic agent. No significant differences were noted between the results obtained in the two experiments. If these results are comparable with those obtained in experimental animals on low-choline diets, the failure of choline to produce a stimulatory effect may indicate that the dietary supply of lipotropic substances or precursors in the persons studied was probably adequate.

\section{ACKNOWLEDGMENTS}

We wish to acknowledge the helpful suggestions and constructive criticism of $\mathrm{Dr}$. Camillo Artom and the technical assistance of Dr. Benjamin Vatz and Mr. Jesse C. Trott, Jr.

The choline used in this study was in the form of tablets of choline dihydrogen citrate, and was supplied by the Department of Clinical Investigation of Parke, Davis and Company, Detroit, Michigan.

\section{BIBLIOGRAPHY}

1. Artom, C., and Cornatzer, W. E., The action of choline and fat on lipide phosphorylation in the liver. J. Biol. Chem., 1947, 171, 779.

2. Perlman, I., Stillman, N., and Chaikoff, I. L., Radioactive phosphorus as an indicator of phospholipid metabolism. XI. The influence of methionine, cystine, and cysteine upon phospholipid turnover in the liver. J. Biol. Chem., 1940, 133, 651.

3. Fishler, M. C., Entenman, C., Montgomery, M. L., and Chaikoff, I. L., The formation of phospholipid by the hepatectomized dog as measured with radioactive phosphorus. J. Biol. Chem., 1943, 150, 47.

4. Zilversmit, D. B., Entenman, C., and Chaikoff, I. L., The measurement of turnover of the various phospholipides in liver and plasma of the dog and its application to the mechanism of action of choline. J. Biol. Chem., 1948, 176, 193.

5. Cayer, D., and Cornatzer, W. E., Radioactive phosphorus as an indicator of the rate of phospholipide formation in patients with liver disease. Gastroenterology, 1950, 14, 1.

6. Hevesy, G., Radioactive Indicators. Interscience Publishers, Inc., New York, 1948.

7. Artom, C., and Fishman, W. H., The relation of the diet to the composition of tissue phospholipids. I. The normal composition of liver and muscle lipids of the rat, with a note on the analytical procedures. J. Biol. Chem., 1943, 148, 405.

8. Artom, C., Phospholipid metabolism in denervated muscles. J. Biol. Chem., 1941, 139, 953. 
9. Fiske, C. H., and Subbarow, Y., The colorimetric determination of phosphorus. J. Biol. Chem., 1925, 66, 375.

10. Tisdall, F. F., A rapid colorimetric method for the quantitative determination of the inorganic phosphorus in small amounts of serum. J. Biol. Chem., 1922, 50, 329.

11. Cornatzer, W. E., and Artom, C., The relation of chemical structure to the stimulation of lipide phosphorylation. J. Biol. Chem., 1949, 178, 775.
12. Entenman, C., Chaikoff, I. L., and Friedlander, H. D., The influence of ingested choline upon cholinecontaining and non-choline-containing phospholipids of the liver as measured by radioactive phosphorus. J. Biol. Chem., 1946, 162, 111.

13. Cayer, D., and Cornatzer, W. E., The effects of choline and methionine on phospholipide formation in patients with liver disease as measured by radioactive phosphorus. Science, 1949, 109, 613. 